\title{
ON THE LOSS OF FINAL $-M$ : PHONOLOGICAL OR MORPHOSYNTACTIC CHANGE?*
}

\begin{abstract}
Summary: This paper intends to show that when grouping the various kinds of omissions of final $-m$ in Väänänen's study on the Vulgar Latin of Pompeian inscriptions, the subcategories in his category b) (' $m$ omis sans raison apparente' i.e. where $-m$ is omitted due to a phonetic process) as "Accusatifs en $-a(m)$ " like Succesus amat ancilla $(m)$ and ad porta $(m)$ Romana $(m)$ or "Accusatifs en -e(m)" such as $q u(a) e$ amas Felicione $(m)$ and ante aede $(m)$ must be rearranged in the following two subcategories: 1 ) cases after prepositions like ad porta $(\mathrm{m})$ Romana $(\mathrm{m})$ and ante aede $(\mathrm{m})$ etc. where besides the phonetic interpretation a parallel morphosyntactic explanation of case confusion cannot be ruled out; and 2) cases with the objective use connected to verbs like Succesus amat ancilla $(m)$ and qu(a)e amas Felicione (m) where, due to the preference of the phonetic interpretation, the morphosyntactic explanation seems to be less probable or even unlikely.
\end{abstract}

Key words: Latin linguistics, Vulgar Latin, morphosyntax, phonology, word-final consonants, inscriptions

In his study on the Vulgar Latin of Pompeian inscriptions, Väänänen dealt with the problem of the dropping of final $-m$ in a peculiar way. ${ }^{1}$ He grouped the omissions of final $-m$ in three categories as follows: a) cases where the omission of $-m$ can be explained by non-phonetic, i.e. technical reasons (e.g. by the lack of space at the end of a line such as ad ampitheatru $(m) \mid{ }^{2}$ or by a potential abbreviation such as plurima $(m)$ salut (em) or before a word-initial $m$ - such as $c u(m)$ media) or morphosyntactic reasons (by confusion of the cases such as the use of the nominative for the accusative, e.g. halica $(m)$... palmas or the ablative for the accusative, i.e. in conventu $(m)$ veni with a facultative explanation by the dropping of final $-m)$; b) where $-m$ is omitted without any reason (' $m$ omis sans raison apparente'), i.e. due to a phonetic process, such as

${ }^{1}$ VÄÄNÄNEN, V.: Le latin vulgaire des inscriptions pompéiennes. Berlin. 1966 ${ }^{3}, 71-77$.

${ }^{2}$ However, the role of the end of a line and thus the concomitant effect of lack of space in the omission of a final consonant is clearly overemphasized in the relevant literature, see ADAMIK, B.: The Problem of the Omission of Word-Final $-s$ as Evidenced in Latin Inscriptions. Graeco-Latina Brunensia 22.2 (2017) 5-21, here 12 n. 14. 
inqua $(m)$ or collegioru(m) and Succesus amat ancilla $(m)$ or ad porta(m) Romana $(m)$ etc.; and c) where a final $-m$ is added hypercorrectly such as peperit die $\{m\}$ Iovis or sine dulcissima $\{m\}$ etc.

Väänänen's categorisation is problematic on more than one account, however. Several items of category b) (' $m$ omis sans raison apparente') could be inserted in category a) as well, since the reason for an omission is not necessarily phonetic; in many cases it can also be morphosyntactic. A considerable part of Väänänen's examples consists of either "Accusatifs en $-a(m)$ " like Succesus amat ancilla $(m)$ and $a d$ porta $(m)$ Romana $(m)$ or "Accusatifs en $-e(m)$ " such as qu(a)e amas Felicione (m) and ante aede $(\mathrm{m})$, which could all be theoretically interpreted also as examples of confusing the cases, and - contrary to items like inqua $(m)$ or collegioru $(m)$ - could therefore be excluded from a purely phonetic analysis.

With the help of the Computerized Historical Linguistic Database of the Latin Inscriptions of the Imperial Age, ${ }^{3}$ the present paper tries to show that in cases like $a d$ porta $(\mathrm{m})$ Romana $(\mathrm{m})$ and ante aede $(\mathrm{m})$ or Succesus amat ancilla $(\mathrm{m})$ and $q u(a)$ e amas Felicione $(m)$ the potential influence of morphosyntactic changes cannot be left out of consideration, since in Vulgar Latin the merger of the accusative and ablative cases was a general process ${ }^{4}$ affecting all declensions both in the singular and in the plural, occurring in prepositional phrases as well as without prepositions. Thus it seems unfounded to leave morphosyntactic explanations out of consideration concerning all or at least some of Väänänen's example types cited above. ${ }^{5}$

1. First we will discuss the prepositional phrases of the type ad porta $(\mathrm{m})$ and ante aede $(m)$ of Väänänen's category b) (' $m$ omis sans raison apparente'). In these items Väänänen admits the phonological explanation by dropping the final $-m$ exclusively, but as we shall see a morphosyntactic explanation by case confusion between the ablative and the accusative seems to be very likely for the following reasons. ${ }^{6}$

Firstly, there are several examples of the confusion of the cases after prepositions in singular which cannot be explained by phonological changes at all. Here I do not mean cases like POST FVNERE for post funus (LLDB-63424), which is to be explained by case confusion only and is therefore exclusively coded by abl. pro acc. in the LLDB Database, i.e. the use of the ablative instead of the accusative. FVNERE could theoretically also be explained by the dropping of the final $-m$, provided that we assume a previous change from the neuter to the masculine gender due to the process of the disappearance of the neuter gender, so this way funere $(m)$ could be interpreted

\footnotetext{
${ }^{3}$ The LLDB data forms referred to in this survey represent the status of the LLDB Database (http://lldb.elte.hu) on 01/09/2018.

${ }_{5}^{4}$ Cf. Herman, J.: Vulgar Latin. Pennsylvania State University Press 2000, 53 f.

${ }^{5}$ See some illustrative examples in ADAMIK (n. 2) 9, in n. 9. Many other inscriptional examples can be found in the relevant parts of related studies such as GAENG, P. A.: Collapse and Reorganization of the Latin Nominal Flection as Reflected in Epigraphic Sources. Potomac, MD 1984; GALDI, G.: Grammatica delle iscrizioni latine dell'Impero (province orientali). Morfosintassi nominale. Roma 2004, and BEU DACHIN, E.: The Latin Language in the Inscriptions of Roman Dacia. Cluj-Napoca 2014.

${ }^{6}$ A phonological change can be assumed also in cases like PER HAC = per hanc (LLDB-25100: $\mathrm{n}(+$ cons. $)>\varnothing /$ abl. pro acc. $)$ etc.
} 
as a masculine accusative by the dropping of $-m$. I mean rather those cases where a phonetic explanation is impossible, such as CVM QVEM for cum quo (LLDB-26800: acc. pro abl.) or can hardly be assumed, as in CVM MARITVM for cum marito (LLDB-46788: acc. pro abl.). ${ }^{7}$

For this type of case confusion in the singular after a preposition, there are a total of 137 data forms in the LLDB Database: 77 items concern the preposition cum (40 times occurring before quem as CVM QVEM for cum quo LLDB-26800: acc. pro abl. and 37 times before other words of the 2nd declension such as CVM A|MICVM for cum amico LLDB-67505: acc. pro abl. etc.). This use of the accusative instead of the ablative can also often be found with other prepositions like in (occurring 39 times, e.g. IN HVNC TV|MVLVM REQVI|ESCIT for in hoc tumulo requiescit, LLDB63471: acc. pro abl.), there are some examples for de (found 6 times, e.g. DE QVEN = de quo, LLDB-40106: acc. pro abl. or, DE LOCVM for de loco, LLDB-46967: acc. pro abl.), for pro (5 times, e.g. PRO MARCIANVM = pro Marciano, LLDB-67577: acc. pro abl.), for $a / a b$ (5 times, e.g. A DOMINVM for a Domino, LLDB-55102: acc. pro abl.), for sub (3 times, e.g. SVB VNC CON for sub hoc consule, LLDB-13815: acc. pro abl.) and for ex (turning up twice, e.g. EX | VITVLVM for ex vitulo, LLDB54390: acc. pro abl.).

To these 137 occurrences in the singular, which can hardly be explained by phonetic processes, are to be added those 21 items where in the neuter gender the accusative singular, formally identical with the nominative, is used instead of the ablative singular, such as EX VOTV $\mid \mathrm{M}$ for ex voto, LLDB-1235: nom./acc. pro abl. and RECESSIT DE SECV|LVM for recessit de saeculo LLDB-16108: nom./acc. pro abl., or SINE CRIME|N for sine crimine, LLDB-66279: nom./acc. pro abl.

All these 158 items in the singular are to be explained exclusively by case confusion, i.e. by the use of the accusative instead of the ablative, while a phonetic explanation is impossible or improbable.

Secondly, we shall discuss here the confusions in the plural after prepositions, since a phonetic explanation is impossible here, too. For this type in the plural we have 56 items in all where the accusative is used for the ablative, on 27 occasions after pro (mostly, i.e. 21 times in the phrase PRO SE ET SVOS for pro se et suis, LLDB-6034: acc. pro abl., but we also have PRO SALVTES I SVAS for pro salutibus suis, LLDB-4822: acc. pro abl. and PRO SALVTE ET REDITVM | ET VICTORIAS for pro salute et reditu et victoriis, LLDB-37003: acc. pro abl. etc.), 15 times after cum (e.g. CVM | FILIOS for cum filiis, LLDB-21620: acc. pro abl. or CVM TEGVLAS for cum tegulis, LLDB-40281: acc. pro abl.), 4 times after in (e.g. IACET IN TENEBRAS for iacet in tenebris, LLDB-32629: acc. pro abl.), 4 times after de (e.g. DE INVICTOS for de invictis, LLDB-29089: acc. pro abl.), 3 times after $a$ / ab (e.g. A COSTOBOCOS for a Costobocis, LLDB-6470: acc. pro abl., AB CONSERVAS | PEDISEQVAS for a conservis pedisequis, LLDB-42799: acc. pro abl.), once after ex (EX VOTA for ex votis, LLDB-1177: acc. pro abl.), once after sine (SINE LIBEROS for sine liberis,

${ }^{7}$ As for CVM MARITVM = cum marito (LLDB-46788: acc. pro abl.), a phonetic explanation is only to be assumed by a complicated and complex process, i.e. by an $\bar{o}>u$ change and a hypercorrect addition of $-m$, which seems unlikely. 
LLDB-4088: acc. pro abl.) and finally once after sub (LLDB-42898: acc. pro abl., SVB TERMAS for sub thermis).

These 56 items are complemented by those 27 occurrences where, conversely, the ablative plural is used instead of the accusative after prepositions (in the LLDB Database coded by dat./abl. pro acc. because of the formal identity of the ablative with the dative), often (16 times) after $o b$ (14 times as in OB MERITIS SVIS for $o b$ merita sua LLDB-72741: dat./abl. pro acc., but we also have OB () AD|FECTIB for $o b$ () adfectus LLDB-70282: dat./abl. pro acc. and OB HO|NORIBVS for ob honores LLDB-58148: dat./abl. pro acc.), six times after inter (e.g. INTER EIS for inter eos LLDB-50612: dat./abl. pro acc. or INTER NOBIS for inter nos LLDB-47039: dat./abl. pro acc.), four times after per (e.g. PER ANNIS for per annos LLDB-42548: dat./abl. pro acc., or PER QVIBVS for per quos, LLDB-63362: dat./abl. pro acc.) once after ad (VADAM | AD FRAGIS for eamus ad fraga LLDB-47111: dat./abl. pro acc.) and once after post (POST DIES () DATIS for post dies datas, LLDB-17314: dat./abl. pro acc.). ${ }^{8}$

Finally, to the 83 items for case confusions in the plural, we have also to add those 21 items where the accusative plural, formally identical with the nominative and therefore coded as nom./acc. pro abl. in the LLDB Database, is used for the ablative plural 7 times after pro as P|RO NOS for pro nobis (LLDB-68148 nom./acc. pro abl.), 4 times after cum such as CVM () SACERDOTES for cum () sacerdotibus (LLDB38217: nom./acc. pro abl.), 3 times after in as INT[ER]|FECTO () IN ALPES IV[LIAS | for interfecto in Alpibus Iuliis (LLDB-11785: nom./acc. pro abl.), 3 times after $a b$ as AB ARTVS for $a b$ artubus (LLDB-64389: nom./acc. pro abl.), 2 times after sine as SINE NV|LLA CRIMINA for sine ullis criminibus (LLDB-8477: nom./acc. pro abl.), once after de as DE VOS for de vobis (LLDB-48288: nom./acc. pro abl.) and once after sub SVB TEMPORA for sub temporibus / tempore (LLDB56156: nom./acc. pro abl. / e > A).

This way we get exactly $(56+27+21=) 104$ examples of case confusion in the plural after prepositions that are not to be interpreted as having any phonetic reason. By adding the $(137+21=) 158$ items in the singular to those in the plural, we have a total of 262 occurrences for the substandard use of the cases after prepositions that are all to be explained exclusively by case confusion, mostly (235 times, $90 \%$ ) by the use of the accusative instead of the ablative or conversely, by the use of the ablative instead of the accusative (which is rare, occurs only 27 times, 10\%): in all these 262 cases a phonetic explanation is impossible or improbable.

Completing this inquiry was important to allow us to argue that if for cases like OB HO|NORIBVS, PER ANNIS, PRO MERITA, C|]VM QVEM and CVM $\mathrm{A} \mid \mathrm{MICVM}$ etc. the phonetic explanation does not arise at all, the morphosyntactic explanation by case confusion cannot be excluded for cases like OB HONORE, PER

${ }^{8}$ Cf. HERMAN (n. 4) 53: "There are also, of course, occasions on which the ablative case appears instead of a correct accusative, particularly after $o b$ (because of), probably due to the influence of pro (for the purpose of); the phrase ob meritis, 'because of his merits', instead of ob merita, is commonly found in the inscriptions". Herman's explanation works only for pro $\sim o b$, but does not work for other prepositions like inter, per etc. 
ORCHESTRA, OB M|EMORIA, CVM | QVAM and CVM CVMPAREM either. This way, contrary to Väänänen's classification, all items like ad porta $(m)$ and ante aede $(m)$ can or even must have a morphosyntactic explanation by case confusion besides the phonological one by dropping the final $-m$. Accordingly, the following cases received such a twofold coding in the LLDB Database: the 149 items like PER ERRORE for per errorem (LLDB-42457: $-\mathrm{m}>\varnothing /$ abl. pro acc.), the 86 items like PER ORCHESTRA for per orchestram (LLDB-44169: nom./abl. pro acc. / -m $>\varnothing)^{9}$ and the 81 items as PER| VALERIO for per Valerium (LLDB-8547: dat./abl. pro acc. / -um $>$ O) all because of PER ANNIS for per annos (LLDB-42548: dat./abl. pro acc.) etc. What is more, this twofold coding also applies to the 176 cases of the hypercorrect addition of a final - $m$ (exemplified by sine dulcissima $\{m\}$ in Väanänen) like PRO SALVTEM| SVAM for pro salute sua (LLDB-4784: acc. pro abl. / -ø>-m) because of PRO SALVTES | SVAS for pro salutibus suis (LLDB-4822: acc. pro abl.). ${ }^{10}$

According to Väänänen's proposal, all these nearly half thousand (492) items with twofold coding after prepositions would have been categorized exclusively by a phonological explanation (either by the dropping of final $-m$ or by the hypercorrect addition of it). However, as we have demonstrated, at the same time, all of them can or even must have a morphosyntactic explanation as well. ${ }^{11}$

2. Before dealing with the problem of case confusion concerning the type Succesus amat ancilla $(m)$ and $q u(a) e$ amas Felicione $(m)$ of Väänänen's category b) (' $m$ omis sans raison apparente'), in this second part those cases will be presented where the confusion between the accusative and ablative, mostly the use of the accusative instead of the ablative, occurs connected to verbs, i.e. in the arguments and the satellites ('adverbials') of verbs and also in other verbal constructions like the ablative absolute clause. Again, the illustrative examples will be taken from the rich material of the LLDB Database.

The use of the accusative instead of the ablative occurs quite often in the arguments of verbs like careo both in the singular and the plural, e.g. CARVI LVCEM for carui luce (LLDB-11297: acc. pro abl. / -ø>-m) where the coding is acc. pro abl.

${ }^{9}$ A formal merger of the ablative with the nominative and the accusative in the singular of the 1 st declension (first by dropping the final $-m$ in the 1 st century BC cf. HERMAN [n. 4] 39, then due to the shortening of the word-final long vowels that happened in the 1 st century AD, also in case endings, see VÄÄNÄNEN [n. 1] 18-19) was certainly possible from the second half of the first century AD.

${ }^{10}$ Though our examples represent mostly prepositional phrases, the same phenomenon is to be experienced for nominal phrases without preposition mostly in indication of the origin of persons like DOMO | ESCVM = domo Oesco (LLDB-72307: acc. pro abl.) in singular of the 2nd declension and like DO|MO LYPIAS = domo Lupiis (LLDB-5286: acc. pro abl.) in plural of the 1st declension (cf. also LLDB16697, LLDB-20273, LLDB-71048, LLDB-71119). We should also mention phrases like PERMISSVM | IVLIORVM = permissu Iuliorum (LLDB-67834: acc. pro abl. / $-\varnothing>-\mathrm{m}$ ) or MARINA NATIONEM | SYRE = Marina natione Syra (LLDB-68864: acc. pro abl. $/-\varnothing>-\mathrm{m}$ ) or NVVELIS ORTVM = nobilis ortu (LLDB-13311: acc. pro abl. / $-\varnothing>-\mathrm{m}$ ) or FELICES AC TRIVMFA|TORIBVS = felicibus ac triumphatoribus (LLDB-50303: nom./acc. pro abl. / decl. II pro III) etc.

${ }^{11}$ Similar cases, e.g. cum iumentum for cum iumento and cum sodales for cum sodalibus are recorded also by VÄÄNÄNEN (n. 1) 121 among the examples of the accusative-ablative confusion after prepositions. 
besides $-\varnothing>-m$, i.e. the explanation by case confusion is secured by the plural variant CARVIT | MINAS SAECVLI for caruit minis saeculi (LDB-20273: acc. pro abl.); or with deponent verbs like utor, fruor, fungor, tueor etc. like in the singular VTERE| () TABERN|AM AVREFI|CINAM for utere taberna aurificina (LLDB-14999: acc. pro abl. / -ø > -m), PATRIA ET | POPVLVM ERVI for patria et populo frui (LLDB11321: acc. pro abl.) or FATVM | FVNCSET for fato functus est (LLDB-60469: nom./acc. pro abl.) and in the plural FRVI | DVLCES ANPLEXVS () ET OSCVLA DATA for frui dulcibus amplexibus () et osculis datis (LLDB-26000: nom./acc. pro abl. / syntactica varia) or FRVI|TVS ET TEMPORA SVMMA for fruitus et temporibus summis (LLDB-50964: nom./acc. pro abl.). Consequently, case confusion cannot be denied for SOCIETATE TVENTVR for societatem tuentur (LLDB-31786: -m > $/$ abl. pro acc.) etc. either.

This substandard use is attested also connected to passive participles like CAPITONI () STATVAM () HONORATO for Capitoni () statua () honorato (LLDB1012: acc. pro abl. / - $>-$ m) or L|OCV CONCESSVM | ARTORIAM FRONTIMAM for locum concessum ab Artoria Frontina (LLDB-20325: acc. pro abl. / -ø > -m) or PROVOCATI TEMPORIS BEATITVDINEM for provocati temporis beatitudine (LLDB-31361: $-\varnothing>-\mathrm{m} /$ acc. pro abl.) and also to deponent participles like VSA () OFFICIVM for usa () officio (LLDB-56055: acc. pro abl.). In the plural the cases, NATVS | CASAS MAIORES for natus Casis Maioribus (LLDB-59514: acc. pro abl.) and THEODOSIO | ET () ARCADIO () GENTOS for Theodosio et () Arcadio () genitis (LLDB-25170: acc. pro abl. / acc. pro dat.) are noteworthy.

There are similar occurrences with passive verbs like CLAVDITVR OC GREMIVM | SPERENDEVS for clauditur hoc gremio Sperendeus (LLDB-2994: nom./acc. pro abl.), and several times in satellites connected to different verbs either in the singular like VOS CONPVTA|TIONEM LIBERARET for vos conputatione liberaret (LLDB-23224: acc. pro abl. / -ø>-m) or in the plural as CO|LETES MANES T[V]|RES for coletis Manes turibus (LLDB-13396: nom./acc. pro abl.) and QVI NOS | DIGNATIONI SVA ET MERITA PROVOCAVIT for qui nos dignatione sua et meritis provocavit (LLDB-28502: nom./acc. pro abl.).

The use of the accusative instead of the ablative occurs many times in satellites of temporal and local specifications connected to different verbs as FELICEM DIEM ORNAMENTVM () [O]FFERAMVS for felici die ornamentum offeramus (LLDB39156: acc. pro abl.) or RECESS CONSVLATVM| () PRIMV| for recessit consulatu primo (LLDB-12728: acc. pro abl. / ø > -m) and ETERNAM SEDE QVIESCIMVS for aeterna sede quiescimus (LLDB-1829: acc. pro abl. / -ø>-m). ${ }^{12}$

The confusion between ablative and accusative is also attested in time expressions after vixit both in the singular like VIXIT () DIEM VNO for vixit () diem unum (LLDB-4862: abl. pro acc. / -um > O) and in the plural like VIXIT | ANNIS DVOS for vixit annos duos or vixit annis duobus (LLDB-4410: acc. pro abl. / dat./abl. pro acc.), IN A|NNI|BVS VIGI|NTI | DVOS for in annos viginti duos or annis viginti

\footnotetext{
${ }^{12}$ Case confusion cannot be excluded for those cases of Väänänen's category c) either (exemplified by peperit die $\{m\}$ Iovis in Väänänen) where a final $-m$ is added hypercorrectly.
} 
duobus (LLDB-63528: acc. pro abl. / dat./abl. pro acc.) and QVEM ABVIT IN [CON]|IVGIO () ANNIS TRES ET M[EN]|SES SEPTE for quem habuit in coniugio () annis tribus et mensibus septem or quem habuit in coniugio () annos tres et menses septem (LLDB-13022: nom./acc. pro abl. / dat./abl. pro acc.) or VIXIT ANNIS LX| MENSES DVOBVS DIES VII for vixit annis LX mensibus duobus diebus VII or vixit annos LX menses duos dies VII (LLDB-8474: nom./acc. pro abl. / dat./abl. pro acc.). ${ }^{13}$

Items in which accusatives interfere with an ablative absolute clause are also indicative of the merger of the accusative and ablative cases. For this phenomenon we have 59 cases in the LLDB Database that are coded as ablativus absolutus accusativis permixtus. Relatively rare are cases like CVR|A AGENTE| VLPIVM| VLPIANVM for curam agente Ulpio Ulpiano (LLDB-953: ablativus absolutus accusativis permixtus) or GERMANO PRAE|SENTE SIMVL CVNCTOSQE | NEPOTES for germano praesente simul cunctisque nepotibus (LLDB-18340: ablativus absolutus accusativis permixtus). In the latter, the confusion in the plural is noteworthy, as also in the following example: ADIVTANTIBVS NEPO|TES SVOS FILIES FILIOS GREGOR|IO ET LAVRENTIO FRATRES for adiutantibus nepotibus suis, filiae filiis, Gregorio et Laurentio fratribus (LLDB-6152: ablativus absolutus accusativis permixtus). Nevertheless, in most (i.e. 41) cases the confusion occurs in the substandard ablative absolute construction of the type se vivo / se vivis, ${ }^{14}$ both in the singular such as SE VIVVM FECIT for se vivo fecit (LLDB-69849: ablativus absolutus accusativis permixtus / accusativus absolutus pro ablativo absoluto) and in the plural like SE VIVOS () COMPARAVERVNT for se vivis comparaverunt (LDB-65368: ablativus absolutus accusativis permixtus / accusativus absolutus pro ablativo absoluto). All these cases of case confusion in se vivo / se vivis constructions are alternatively coded as accusativus absolutus pro ablativo absoluto, since here the reflexive pronoun se can be regarded not only as an ablative but also as an accusative.

In this context also those few cases have to be taken into consideration where all constituents of an ablative absolute clause are undoubtedly put in accusatives and are therefore called an accusative absolute construction like VIVENTES | CARDILIVM | ET AVITAM | FELIX TVRRE for viventibus Cardilio et Avita felix turris (LLDB28603: accusativus absolutus pro ablativo absoluto), M () F () CLODI|ANVS () CVRAN|TES FILIOS | EIVS for monumentum () fecit Clodianus () curantibus filiis eius (LLDB-44026: accusativus absolutus pro ablativo absoluto) and CONSTANTIVS ET SOSANNA | () EMERVNT | PRESENTIS OMNIS FOS|SORES for Constantius et Susanna () emerunt praesentibus omnibus fossoribus (LLDB-57141: accusativus absolutus pro ablativo absoluto).

\footnotetext{
13 This way the occurences of the confusion between ablative and accusative in time expressions after vixit (e.g. VI[XIT A]NNIS | () MENSES () DIES = vixit annos () menses () dies / annis () mensibus () diebus LLDB-10167: dat./abl. pro acc. / nom./acc. pro abl., or ANNOS VIXIT X | MENSIBVS VII DIEBVS $\mathrm{XXIII}=$ annis vixit X mensibus VI diebus XXIII / annos vixit X menses VI dies XXIII LLDB-54252: acc. pro abl. / dat./abl. pro acc.) may be listed among the examples of the ablative-accusative merger, contrary to the assumption of SUÁREZ MARTÍNEZ, P. M.: Vixit annis XXX menses III dies XIX. In HERMAN, J. (ed.): Linguistic Studies on Latin. Selected Papers from the 6th International Colloquium on Latin Linguistics (Budapest, 23-27 March 1991). Amsterdam-Philadelphia 1994, 55-63.

${ }^{14}$ For this construction, see ZELENAI, N.: The Variants of the se vivo fecit Expression in Latin Language Inscriptions. Graeco-Latina Brunensia 23.1 (2018) 227-244.
} 
From the above it is clear that case confusion between the accusative and the ablative happened due to the functional merger of the two cases that eventually resulted in the formation of a merged accusative-ablative case. ${ }^{15}$ This has to be taken into consideration for all types discussed here, especially the occurrences after prepositions and also all structures without prepositions and connected to verbs of no $o b$ jective function since case confusion occurs also in the plural of all these types.

3. Finally, in the third part we deal with the problem of the type Succesus amat ancil$l a(m)$ and $q u(a) e$ amas Felicione $(m)$ recorded by Väänänen exclusively as the result of the dropping of final $-m$. Theoretically, a facultative morphosyntactic explanation by case confusion between the ablative and the accusative can also be taken into consideration here, especially regarding the direct objects ancilla $(\mathrm{m})$ and Felicione $(\mathrm{m})$. In the LLDB Database we find various examples (ca. 680) of this phenomenon, many (ca. 450) occurrences in the singular of the 1st declension as ARA POSVIT for aram posuit (LLDB-14797: nom./abl. pro acc. / -m > $),{ }^{16}$ several (ca. 80) items in the singular of the 2nd declension as TITVLO PO|S for titulum posuit (LLDB-17619: dat./abl. pro acc. / -um > O) and numerous (ca. 145) items in the singular of the 3rd declension HABVIT PATRE LAOMEDONTE| for habuit patrem Laomedontem (LLDB-43608: abl. pro acc. / $-\mathrm{m}>\varnothing$ ), ${ }^{17}$ as well as some items of the singular of the 4th and 5th declensions like DVOVIRATV EGIT for duoviratum egit (LLDB-72890: $-\mathrm{m}>\varnothing /$ abl. pro acc.) and REQVE () DEDIT for requiem () dedit (LLDB-4207: -m > $\varnothing /$ abl. pro acc.). All these items have a double, i.e. phonetic and morphosyntactic coding in the LLDB Database, but according to Väänänen's methodology all would be coded only by a single phonetic code.

The only questionable and problematic issue here is whether we are entitled to assume a case confusion between the accusative and the ablative, more precisely the use of the ablative for the accusative for items with a dropped $-m$ such as MEMORIA POSVERVNT for memoriam posuerunt (LLDB-60973: nom./abl. pro acc. / -m > ø), i.e. for the objective use of the accusative. Contrary to the occurrences after prepositions (dealt with in the first part) and to the occurrences connected to verbs of no objective function (dealt with in the second part), we barely have any examples of this kind of confusion with the objective use in the plural: we have not found faulty phrases like curis egit for curas egit, memoriis posuit for memorias posuit and arcis

${ }^{15}$ On the merger of accusative and ablative see e.g. GAENG (n. 5) 47-49.

16 The most frequent are cases like CVRA EGERVNT = curam egerunt (LLDB-43706: nom./abl. pro acc. / -m >ø, 43 times, mostly with present participle agentes, agente, agentibus etc.), MEMORIA POSVERVNT = memoriam posuerunt (LLDB-60973: nom./abl. pro acc. / -m > $>$, 57 times with several verbal variants as fecit, posuit etc.), ARCA POSV|ERVNT = arcam posuerunt (LLDB-9409: -m >ø / nom./abl. pro acc., 24 times constructed with several verbs like fecit, comparavit etc.), ARA POSVERVNT = aram posuerunt (LLDB-73319: nom./abl. pro acc. $/-\mathrm{m}>\varnothing, 61$ times constructed mostly with posuit) and [V]IXIT VITA | [B]ONA = vixit vitam bonam (LLDB-15162: -m >ø / nom./abl. pro acc., 28 times composed of various verb forms like perdidit, finiverunt etc.); sometimes it occurs also for the predicative use in objective phrases like CAVSAM () IVSTA () CENSVERIT = causam iustam censuerit (LLDB22925: $-\mathrm{m}>\varnothing /$ nom./abl. pro acc.).

${ }^{17}$ Sometimes also for the predicative use in objective phrases like |VT ME () COMPOTE FACIAS| $=$ ut me () compotem facias (LLDB-31887: abl. pro acc. / $-\mathrm{m}>\varnothing)$. 
comparavit for arcas comparavit etc. in the inscriptions. Based on the rates after prepositions, where the ablative was used instead of the accusative in $10 \%$ of the records, we would expect to have at least in ca. $10 \%$ of all plural phrases like memorias posuit etc. occurrences of faulty phrases like memoriis posuit etc. However, this is not the case, as we will demonstrate below.

This potential counter-argument based on the relative rarity or even lack of confusion between the accusative and the ablative as for the objective use of the accusative (of the type curam egit, memoriam posuit, arcam comparavit etc.) in the plural as evidenced in inscriptions has a weak point. While it could be an argument against the morphosyntactic explanation, it could probably be offset by the frequency analysis to be presented in the following Table 1 (executed on the inscriptional material with the help of the EDCS ${ }^{18}$ ), which shows that the relevant plural phrases are actually either non-existent (e.g. we have no arcas posuit, only arcam posuit etc.) or extremely rare (memorias fecit or comparavit occurs only twice while memoriam fecit or posuit etc. occur very often). $99 \%$ of the phrases selected in Table 1 occur in the singular and only $1 \%$ in the plural, which would mean that in the inscriptional material a case confusion between the accusative and the ablative would not have a chance to appear in the plural.

\begin{tabular}{|c|c|c|c|c|c|}
\hline \multicolumn{6}{|c|}{ Incidences of objective phrases in the plural measured against those in the singular } \\
\hline $\begin{array}{c}\text { curam } \\
\text { agere }\end{array}$ & $\begin{array}{c}\text { memoriam } \\
\text { ponere etc. }\end{array}$ & $\begin{array}{c}\text { arcam } \\
\text { ponere etc. }\end{array}$ & $\begin{array}{c}\text { aram } \\
\text { ponere } \text { etc. }\end{array}$ & $\begin{array}{c}\text { vitam } \\
\text { finire } \text { etc. }\end{array}$ & $\begin{array}{c}\text { singular } \\
\text { total }\end{array}$ \\
\hline 265 & 578 & 135 & 910 & 272 & $\begin{array}{c}\text { 2160 } \\
\text { (ca. 99\%) }\end{array}$ \\
\hline 1 & 2 & 0 & 22 & 2 & $\begin{array}{c}\text { 27 } \\
\text { (ca. 1\%!) }\end{array}$ \\
\hline $\begin{array}{c}\text { curas } \\
\text { agere }\end{array}$ & $\begin{array}{c}\text { memorias } \\
\text { ponere } \text { etc. }\end{array}$ & $\begin{array}{c}\text { arcas } \\
\text { ponere } \text { etc. }\end{array}$ & $\begin{array}{c}\text { aras } \\
\text { ponere } \text { etc. }\end{array}$ & $\begin{array}{c}\text { vitas } \\
\text { quaerere } \text { etc. }\end{array}$ & $\begin{array}{c}\text { plural } \\
\text { total }\end{array}$ \\
\hline
\end{tabular}

Table 1

However nice and convincing this frequency analysis may appear, it is not conclusive because of the word olla 'cinerary urn' (primarily attested in the funerary inscriptions of the city of Rome), for which there are not only several occurrences in the plural, but their number even exceeds that of the singular (e.g. LLDB-18917: -m $>\varnothing /$ nom./abl. pro acc., PATER D OLA = pater dat ollam; see table 2 below $)^{19}$ and despite this fact there are no examples of case confusion in the plural: we do not have substandard phrases such as ollis dedit / donavit etc. for ollas dedit / donavit etc., though we should have them at a rate of at least in ca. $10 \%$ of all occurrences. Consequently, the examples referred to in Table 1 above might not be representative of this problem, since they are (mostly or entirely) used in the singular only. Thus, with re-

\footnotetext{
${ }^{18}$ Epigraphik-Datenbank Clauss / Slaby cf. http://db.edcs.eu/epigr/.

${ }^{19}$ Cf. also LLDB-42565: - $\mathrm{m}>\varnothing$ / nom./abl. pro acc., OLLA VNA DEDIT = ollam unam dedit (in LLDB Database we have 14 occurrences composed mostly of verbs like dat, dedit, donavit, emit).
} 
gard to the high number of occurrences for ollas dare etc. alongside ollam dare etc., we cannot cite the non-existence or extreme rarity of plural forms as a potential explanation for the non-existence or extreme rarity of case confusion in the plural forms as for the objective use of the accusative.

\begin{tabular}{|c|}
\hline $\begin{array}{c}\text { Incidences of objective phrases in the plural } \\
\text { measured against those in the singular: olla }\end{array}$ \\
\hline $\begin{array}{c}\text { ollam } \\
\text { dare etc. }\end{array}$ \\
\hline $\begin{array}{c}127 \\
(36 \%)\end{array}$ \\
\hline 228 \\
$(64 \% !)$ \\
ollas \\
dare etc. \\
\hline
\end{tabular}

Table 2

What is more, we have found 3 examples for the case confusion, i.e. the use of the accusative for the ablative in the case of olla in the plural but only after prepositions as in CVM OLAS for cum ollis (LLDB-77798: acc. pro abl., CIL VI 25359, 7) and cum ollas duas for cum ollis duabus (CIL VI 28759, 3) or de olas for de ollis (CIL VI $29983,2)$. This means that what we have stated about the case confusions after prepositions applies to olla, too. The evidence of the word olla, however, must not be overestimated because its attestation is very limited both geographically and chronologically, since nearly all occurrences come from the city of Rome and from the preChristian era, thus they only bear witness to the first three centuries AD and to the capital of the Roman Empire. $^{20}$

The remaining rare examples for the accusative-ablative confusion in the plural as for the direct object may have to be explained by another factor or by other factors. For example QVAE ANNOS AETATIS AGENS SEX ET DECE MESIB OCTO for quae annos aetatis agens sex et decem menses octo (LLDB-66838: dat./abl. pro acc., CIL VI 23629, 6), where agens is composed first with the accusative annos but then with the ablative mensibus, both the impact of case variation after vixit and metrical factors (metri causa solution) have to be taken into consideration. In another example in the plural, i.e. VERVS PROF EST () FVND TAVRIANIS DOVB| for Verus professus est () fundos Taurianos duos, (LLDB-61387: dat./abl. pro acc.), the case confusion ${ }^{21}$ can be explained by textual linguistic reasons as well,

${ }^{20}$ In EDCS there is only one occurrence labelled as Christian (CIL VI $28576=$ ICUR VII 19465) but it dates to the 1 st century AD (ICUR comments as: inscriptio... fortasse ne christiana quidem). However, in EDCS there is another item of olla in an inscription dated to 351-400, CIL VI 537: vivax sit spiritus ollis (in a hexameter).

${ }^{21}$ Attested in the long text of the Tabula Alimentaria (CIL XI 1147, VI 85, Aemilia / Regio VIII, Veleia, $107 \mathrm{AD})$ also in the singular such as LLDB-61384: dat./abl. pro acc. / -um > O, VERVS PROF 
since there are several territorial delimitations in the ablative among and around these declarations of properties ${ }^{22}$ constructed by the verb profiteor with the accusative. In a curse tablet from early Baetica, the case confusion in plural evidenced by ROGO () DEIBVS for rogo () deos (LLDB-45769) or ROGO ORO ()| EINFEREIS for rogo oro () inferos (LLDB-78600) can be explained by the confusion of the phrase rogare deos with the construction petere a deo. ${ }^{23}$

4. Based on the above, we can draw the conclusion (though with some caution) that with respect to the lack of the accusative-ablative confusion in the plural as for the direct object in phrases like memoriam posuit, ollam dedit etc. we cannot regard items like memoria $(\mathrm{m})$ posuit or olla $(\mathrm{m})$ dedit as examples for the use of the ablative instead of the accusative (coded as nom./abl. pro acc. or abl. pro acc. in the LLDB Database) but only for the dropping of final $-m$ (coded as $-m>\varnothing$ in the LLDB Database).

However, for such a radical conclusion, a counter-argument could be raised, ${ }^{24}$ which would refer to a potential chronological difference between the singular and the plural regarding the speed of case mergers by assuming that the merger was much slower and more retarded in the plural than in the singular, since as Herman formulates "in the plural, the great majority of the phonetic distinctions on which the inflectional distinctions depended were stable and survived." ${ }^{25}$ Accordingly, until the replacement of the grammatical cases by the use of prepositions (such as de plus ablative in

EST () FVND EPPIANO TITIOLANO HISTRIODVNO = Verus professus est () fundum Eppianum Titiolanum Histriodunum.

${ }^{22}$ E.g. as for COLLINVS PROF EST () FVNDO OLYMPIANVM = Collinus professus est () fundum Olympianum (LLDB-61365: dat./abl. pro acc. / -um > O, CIL 11, 1147, III 81) see the clause before the mistaken fundo for fundum: qui sunt (= est) in Veleiate pag(o) Ambitrebio, adf(inibus) Mommeio Persico et Virio Severo et pop(ulo); et fundo(= fundum) Olympianum.

${ }^{23} \mathrm{Cf}$. also the obscure case of LLDB-55292: dat./abl. pro acc., AETERNOS SATVRNINVS TERMINAT ANIS $\|=$ aeternos Saturninus terminat annos). As for the rare use of the ablative instead of the accusative in the plural as the direct object in late literary sources see note 25 below.

${ }^{24}$ Another counter-argument is a limited one, referring to the phrase type of cura $(\mathrm{m})$ egerunt / egit: here in the case of CVRA AGENTE = curam agente (for LLDB-47601: nom./abl. pro acc. / $-\mathrm{m}>\varnothing$, 19 times in LLDB) and CVRA AGENTIBVS = curam agentibus (LLDB-945: nom./abl. pro acc. / -m > $>$, 9 times in LLDB) the impact of the ablative case, i.e. the influence of the ablative absolute construction on to the object $\operatorname{cura}(\mathrm{m})$ can be assumed very probable.

${ }^{25}$ Cf. HeRMAN (n. 4) 53 and also 58-59: "The speech of more educated groups, influenced by daily contact with biblical and liturgical texts that still maintained the ancient inflections, may have been a bit different; to them the phonetically stable and distinctive endings such as -ibus (dative and ablative plural of third-declension nouns) and -arum and -orum (genitive plural of first- and second-declension nouns respectively) probably sounded solemn and important, even if also archaic. It has been noted that even in the most markedly 'vulgar' Merovingian texts, these forms, when they are found (and they are), are used in the normal way, with their correct functions." It is still worth mentioning that the accusativeablative confusion, i.e. the use of the ablative for the accusative in the plural as the direct object is rarely attested - but still attested also in the literary sources of the 6th and 7th centuries, for example in the Histories of Gregory of Tours, cf. BonNET, M: Le latin de Grégoire de Tours. Paris 1890, 529: misit nuntios comitibus ducibusque vel reliquos agentibus 6, 19 p. 288, 11 (edd. Krusch \& Levison), and in the chronicles known under the name Fredegar, cf. HAAG, O.: Die Latinität Fredegars. RomForsch 10 (1899) 835-932, here 879: e.g. omnes seniores, ponteveces, ducebus et primatis . . ad se venire precepit 4, $89 \mathrm{p}$. 165, 32; omnem exercitum . . tam ducibus, comitibus, vel omnes maiores natu . ammisit cont. 37 p. 184 , 13; comites suos, scaritos et leudibus suis . . transmisit cont. 52 p. 192, 13 (ed. Krusch). 
the function of a genitive and $a d$ plus accusative for the dative) entirely and definitively in the 6th or even more likely in the 7th century AD (after the rare beginnings in 4th and 5th centuries), the case system in the plural protected by the stable phonetic distinctions might have been less liable to disintegration than in the singular. ${ }^{26}$

However, this argument does not seem to be very decisive here. As we have demonstrated, case confusions between the accusative and the ablative (mostly the replacement of the ablative by the accusative) are definitely present also in the plural of the prepositional phrases and also without prepositions, as well as in connection with verbs except for the direct-object function expressed by the accusative.

To sum up, the subcategories in Väänänen's category b) (' $m$ omis sans raison apparente') as "Accusatifs en $-a(m)$ " like Succesus amat ancilla $(m)$ and ad porta(m) Romana $(m)$ or "Accusatifs en $-e(m)$ " such as $q u(a) e$ amas Felicione $(m)$ and ante aede $(m)$ must be rearranged in the following two subcategories: 1) cases like ad porta $(\mathrm{m})$ Romana $(\mathrm{m})$ and ante aede $(\mathrm{m})$ etc., where besides the phonetic interpretation by the dropping of the final $-m$ a parallel morphosyntactic explanation by case confusion cannot be ruled out; and 2) cases like Succesus amat ancilla(m) and qu(a)e amas Felicione $(m)$ where by preferring the phonetic interpretation the morphosyntactic explanation seems to be less probable or even unlikely. ${ }^{27}$

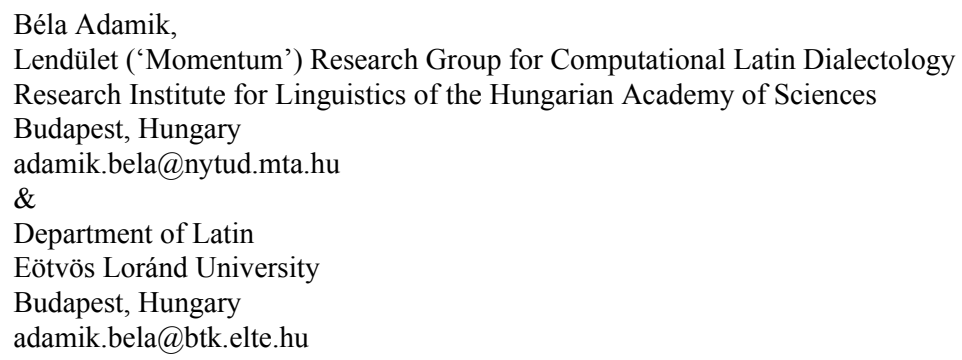

Open Access. This is an open-access article distributed under the terms of the Creative Commons Attribution 4.0 International License (https://creativecommons.org/licenses/by/4.0), which permits unrestricted use, distribution, and reproduction in any medium, provided the original author and source are credited, a link to the CC License is provided, and changes - if any - are indicated. (SID_1)

${ }^{26}$ Both constructions that had a decisive role in the final disintegration of the case system are relatively often attested in Hispania in the Visigoth slate tablets of the 7th century. The de plus ablative construction in the function of a genitive can be found 15 times in the Visigothic slate tablets of Lusitania, e.g. LLDB-47046: de + abl. pro gen., VINDO PORTIONE| DE TERRA = vendo portionem terrae, and the $a d$ plus accusative construction in the function of a dative four times, e.g. LLDB-60035: ad + acc. pro dat., $\mathrm{AD}$ EVM DICENS = ei dicens.

${ }^{27}$ Consequently, in the LLDB Database concerning the cases of the type 2), the relevant morphosyntactic codes were replaced by code variants with the extension 'in obiecto directo' such as in LLDB14797: $-\mathrm{m}>\varnothing /$ nom./abl. pro acc. in obiecto directo, ROGATVS () ARA POSVIT = Rogatus () aram posuit, LLDB-17619: dat./abl. pro acc. in obiecto directo / -um > O, TITVLO PO|S = titulum posuit, LLDB-43608: abl. pro acc. in obiecto directo / $-\mathrm{m}>\varnothing$, HABVIT PATRE LAOMEDONTE $\mid=$ habuit patrem Laomedontem. Thus from now on, these items can be treated separately from the other relative morpho-syntactic codes in the LLDB Database, and be either included in or excluded from a morphosyntactic or a phonetic survey. 